\title{
An investigation of the relationship between teachers' expectations and teachers' perceptions of student attributes
}

\author{
Anneke C. Timmermans ${ }^{1} \cdot$ Hester de Boer ${ }^{1}$. \\ Margaretha P. C. van der Werf ${ }^{1}$
}

Received: 18 February 2015/ Accepted: 8 November 2015/Published online: 8 February 2016

(C) The Author(s) 2016. This article is published with open access at Springerlink.com

\begin{abstract}
Little is known about factors other than students' abilities and background variables that shape teachers' achievement expectations. This study was aimed at investigating the role of teachers' perceptions of students attributes (working habits, popularity, self-confidence, student-teacher relationships, and classroom behavior) in shaping teachers' expectations. The sample analyzed consisted of 5316 students and 469 classes in grade 6 in Dutch primary education. Teachers had higher expectations for students who they perceived as self-confident and having positive work habits. Differences in expectations between boys and girls could partly be explained by the teachers' perceptions of students' work habits. Teachers differed in the extent to which they let their perceptions of student attributes shape their expectations.
\end{abstract}

Keywords Teacher expectations - Teacher perceptions - Student attributes · Multilevel analysis · Between-teacher differences

\section{Introduction}

In the international context, researchers have been interested in teacher expectations as a possible mechanism through which the achievement gap between majority and minority students, boys and girls, and students from more or less affluent families could emerge and grow (e.g., Glock and Krolak-Schwerdt 2013; Jussim et al. 1996; McKown and Weinstein 2008; Riley and Ungerleider 2012; Sorhagen 2013). In the Netherlands, an ongoing debate has taken place in recent decades concerning the

Anneke C. Timmermans

a.c.timmermans@rug.nl

1 Groningen Institute of Educational Research (GION), University of Groningen, Grote Rozenstraat 3, 9712 TG Groningen, The Netherlands 
accuracy of the teachers' expectations at the end of primary education and the possible consequences of inaccurate expectations on track placement of students in the first year of secondary education (e.g., de Boer et al. 2010; Driessen 2005, 2011; Timmermans et al. 2015). Although this debate initially focused on ethnic minority groups in general, attention gradually shifted to equity in educational opportunities of students from Turkish and Moroccan backgrounds, as they constitute the largest minority groups in the Netherlands.

However, little is known about factors other than students' abilities and background variables that shape teachers' expectations of the future academic performance of their students (Hecht and Greenfield 2002; Hughes et al. 2005; Rubie-Davies 2008, 2010). Nonetheless, it is important to understand which factors, personal impressions, or perceptions shape teachers' expectations (Hughes et al. 2005; LaVoie and Adams 1973), because the teachers' expectations may influence subsequent teacher behavior, student performance, and track placement (e.g., Bennet et al. 1993; Brophy and Good 1970; Hamre and Pianta 2006; Helwig et al. 2001; Ready and Wright 2011; Rubie-Davies 2007, 2008, 2010). In shaping expectations of the future academic performance of students, teachers may partly rely on their perceptions of students' behavior in the classroom and the students' motivation while working on tasks (e.g., Bennet et al. 1993; Driessen 2006; Hughes et al. 2005; Kelly and Carbonaro 2012). Although it is generally assumed that teachers use these perceptions of student attributes in shaping expectations (RubieDavies 2008), the empirical evidence for an association between teachers' perceptions of student attributes and their expectations for students' future academic performance is rather limited. The question therefore remains "What are the relations between teachers' perceptions of current attributes of pupils and their expectations for the future performance of the pupils?" (Hoge 1984, p. 216) and to what extent can these perceptions of student attributes be seen as an explanation of why teachers have lower or higher expectations for particular groups of students. According to Rubie-Davies (2010), this is a worthy area of research because an increased understanding of the association between teacher expectations and perceptions of student attributes may ultimately assist in isolating teacher and student characteristics that appear to have important consequences for student social and academic outcomes. The aim of the present study is therefore to contribute to the body of knowledge on this relationship between teacher expectations and perceptions by investigating why, for some (groups of) students, the expectations of their teachers concerning the future academic performance do not correspond to their current academic performance.

\subsection{Teacher expectations}

Teacher expectations and the impact of those expectations on subsequent student performance have been investigated in a long tradition, starting with Rosenthal and Jacobsen's (1968) controversial experimental study Pygmalion in the Classroom. In that study, it was demonstrated that when teachers expected students to perform at a high level, students tended to confirm this expectation. This phenomenon became known as the self-fulfilling prophecy, as originally defined by Merton (1948). Many 
researchers have investigated the self-fulfilling prophecy effect of teacher expectations on future performance of students in both naturalistic and experimental settings, concluding that self-fulfilling prophecies generally seem to have only relatively small effects on student achievement (Jussim and Harber 2005; RubieDavies 2008). In this research tradition the term "teacher expectations" refers to inferences made by teachers with respect to students' potential to achieve based on the teachers' current knowledge about these students (Good 1987; Riley and Ungerleider 2012). Teacher expectations have also been described as follows: "Expectations are primarily cognitive phenomena, inferential judgments that teachers make about probable future achievement and behavior based upon the student's past record and his present achievement and behavior" (Brophy and Good 1974, p. 129).

Because only inaccurate expectations can lead to self-fulfilling prophecies (Merton 1948; Madon et al. 2011), another body of literature relates to whether there are particular subgroups of students for whom the teachers' inferences on future academic performance are less accurate. Mostly, the accuracy of teacher expectations is established based on the correspondence between the teacher's expectations and the previous performance of the students (e.g., Alvridez and Weinstein 1999; Cooper et al. 1982; de Boer et al. 2010; Hinnant et al. 2009), as the expectations are supposed to be informed inferences based on past records and current behavior and performance. Demographic characteristics of students and their families, such as socio-economic status, minority status, and gender (RubieDavies 2008), are the most common variables investigated in relation to teacher expectations. Differential teacher expectations, or teacher expectation bias, can occur when teachers systematically expect too much or too little from specific groups of students (van den Bergh et al. 2010). Studies focusing on naturally occurring differential teacher expectations for demographic characteristics of students and their families have thus far resulted in inconsistent findings (Alvridez and Weinstein 1999; McKown and Weinstein 2008). In their review, Jussim and Harber (2005) conclude that teachers are not biased because the differences in teacher expectations for stigmatized demographic student subgroups closely correspond to differences in those groups' academic performance in previous grades and achievement tests. However, a substantial number of studies published after Jussim and Harber's (2005) review have found significant differences in teacher expectations for students of different demographic groups after the previous performance of students was controlled for (e.g., Glock and Krolak-Schwerdt 2013; McKown and Weinstein 2008; Rubie-Davies et al. 2006; Speybroeck et al. 2012; Tenenbaum and Ruck 2007; van den Bergh et al. 2010). Generally, for students with equal performance records, teachers tend to have lower expectations for future academic performance when the student comes from a less affluent family and when the student is a boy.

\subsection{Teacher perceptions of student attributes and expectations}

The above literature review showed that inaccurate teacher expectations have an impact on students' academic performance and that teacher expectations can be 
biased towards certain subgroups of students. It is assumed, though, that teacher expectations not only depend on student background characteristics, but also on teachers' perception of student attributes such as working habits, popularity, selfconfidence, student-teacher relationships, and classroom behavior. The empirical evidence for an association between teachers' perceptions of student attributes and their expectations for students' future academic performance is rather limited, but there are several prior studies that have focused on this subject.

Teachers' expectations for the academic achievement of primary school students have been found to be positively related to students' perceived assertiveness, independence (Alvridez and Weinstein 1999; Bonvin and Genoud 2006; Rubie Davies 2010), and self-confidence (Driessen 2006; Rubi-Davies 2010). These studies indicate that teachers tend to have higher expectations of a student if they perceive the student as independent and more confident. Moreover, teachers' expectations were found to be associated with their perceptions of the students' social behavior in the classroom (Bennet et al. 1993; Driessen 2006; Hecht and Greenfield 2002; LaVoie and Adams 1973) and engagement (Kelly and Carbonaro 2012; Rubie-Davies 2010). For example, in an experimental study among 350 teachers, LaVoie and Adams (1973) found that children for whom teachers perceived low grades in personal and social growth, work habits, and attitudes, were predicted to have less ability and lower aspirations than children with acceptable conduct. Similarly, Kelly and Carbonaro (2012) found that after differences in performance levels between students were controlled for, the teachers' perceptions of student engagement in class consistently explained differences in teacher expectations between students. In this particular study, student engagement was indicated by students' (a) effort, (b) frequency of doing homework, (c) attentiveness, and (d) disruptiveness. The teachers' expectations for students' academic performance were higher when the teachers' perceptions of the students' engagement were higher. A plausible explanation for this finding is that engaged students tend to be more compliant and exhibit appropriate classroom behavior, which may have contributed to their teachers' positive assessments and expectations (Rubie-Davies 2008). Finally, it has been found that the quality of the student-teacher relationship, as perceived by the teacher, is more closely related to teachers' expectations than the children's measured performance and background (Hughes et al. 2005; RubieDavies 2010). Teachers had higher expectations of academic performance for students for whom they perceived a more positive student-teacher relationship.

\subsection{The present study}

The aim of the present study was (1) to contribute to the body of knowledge on the relationship between teacher expectations and teacher perceptions of student attributes such as working habits, popularity, self-confidence, student-teacher relationships, and classroom behavior and (2) to investigate to what extent teacher perceptions of student attributes may explain why for some (groups of) students the expectations of their teachers concerning the future academic performance do not correspond to their current academic performance. The previous studies have usually been focused on one particular aspect of teacher perceptions instead of a 
simultaneous analysis of teacher perceptions on multiple aspects of student behavior. In the present study, we focused on a wider range of teacher-perception variables of student attributes, including the perceived student-teacher relationship, self-confidence, work habits, popularity, and social behavior. Furthermore, previous studies have usually focused on the unique predictions of teacher perceptions of student attributes on their expectations of the students future academic potential, but in the context of teacher expectations far less attention has been given to interactions between teacher perceptions of student attributes and student performance or background characteristics. However, there seems to be some potential of this relationship as there is a growing body of literature suggesting that teachers have more of a tendency to perceive certain groups of students, for example boys or minority students, as "inherently" having particular attributes such as "good behavior", "solid work ethic", "socially adaptable", "more detached", or "more likely to misbehave" (e.g., Reyna 2000; Riley and Ungerleider 2012). This tendency may very well be reflected in the teachers' expectations of the future academic performance or success of the students. In the current study we investigated whether the relation between teachers' perceptions of students' classroom behavior and teachers' expectations of students depended on the achievement levels of the students. And finally, we investigated differences among teachers in expectations. Our research questions were as follows.

1. After controlling for student performance and background characteristic, are teachers' expectations of future students' performance related to their perceptions of student attributes?

2. To what extent can teachers' perceptions of student attributes account for differences found in expectations for different demographic subgroups of students?

3. Does the association between teacher expectations and perceptions of attributes differ among teachers?

4. Is the relation between teachers' perceptions of student attributes and teachers' expectations of students dependent on the achievement levels of the students?

\section{Method}

\subsection{Sample}

The empirical analyses were based on measurements of the PRIMA cohort studies conducted in 2004/2005 (Driessen et al. 2006). The total cohort consisted of a sample of 420 primary schools that were representative of Dutch primary schools, supplemented with a sample of 180 schools with relatively high proportions of minority students, to ensure that sufficient variation in school composition was available in the total sample. For this particular study only those students in the final grade of primary education in 2004/2005 were used; this is comparable to grade 6 in the U.S. (age approximately 11-12 years). The total sample of grade 6 students in 
this dataset consisted of 13,847 students. For a selective subsample of 5316 students, information was available for teacher expectations, previous performance, demographic background, and teachers' perceptions of their classroom behavior. The students in the subsample were nested in 469 classes and 388 primary schools.

\subsection{Context}

This study was conducted in the context of Dutch primary education and the transition to secondary education. Dutch primary education is intended for all children from age 4 (pre-kindergarten) up to and including age 12 (grade 6). In 2013, approximately $1,500,000$ pupils were enrolled in 6500 primary schools (Ministry of Education 2014). During primary education many schools monitor the progress of their students by means of so-called Monitoring and Evaluation systems, that is, systems that consist of series of tests administered by schools, mostly for their own use. In the final grade, about $85 \%$ of the schools administer the "Cito school leavers test"; a standardized test consisting of the basic subjects that was designed to help teachers formulate a track recommendation for secondary education. The track recommendation each student received at the end of primary education is usually considered as the expression of the teacher's expectation for the student's future performance during secondary education (e.g. de Boer et al. 2010; Inspectorate of Education 2007).

Students in Dutch secondary education are placed in a specific track based on their scholastic aptitude (track recommendation and score on the school leavers test). In total there are five ordered track-levels in Dutch secondary education. The duration of the tracks varies between four (the three lowest tracks) and six years (the highest track) and each track offers different access to further education. The preuniversity track (the highest track), which takes six years, is the only one that directly prepares students for university education. Higher general secondary education is the second highest track (lasting 5 years) and prepares the student for further education in higher vocational education or universities for applied sciences. The three pre-vocational education tracks (each lasting 4 years) prepare the students for further education in senior secondary vocational education, although these prevocational education tracks differ in level and further educational opportunities. Grade repetition within tracks and intermediate upward or downward mobility between the tracks is possible, as students can change tracks depending on their grades. However, the extent of intermediate down- and upward mobility is limited as after three years in secondary education $85 \%$ of the students are still in the track of the teachers' track recommendation (Inspectorate of Education 2014). After controlling for student achievement, the track recommendations are highly predictive of initial track placement. These effects dissipate partly during the first two years of secondary education and then remain stable in the higher grades of secondary education (de Boer et al. 2010). 


\subsection{Instruments}

The variable of focal interest in this study was "teacher expectations". Four performance variables were available, as was information on the students' gender and socio-ethnic backgrounds. The four performance variables reflect measures of the current student performance (school leavers test) and their past records (tests from monitoring systems). Teacher expectations were defined as inferential judgments based upon the student's past record and his or her present achievement and behavior. Finally, data about teachers' perceptions of the students' classroom behavior were collected. This was measured using the student profiles that teachers were asked to complete for each student in their class. Descriptive statistics of the variables described below can be found in Table 1 .

\subsubsection{Teacher expectations}

Teacher expectations were operationalized using the track recommendations given by teachers for their students at the end of primary education. This track recommendation is considered an informed expectation of the teacher indicating which track is the most optimal for a student given the student's potential. The recommendation was measured using a teacher questionnaire in which teachers could choose the most optimal tracks in secondary education for each student. Teachers were allowed to choose two adjacent tracks. The recommendations were

Table 1 Descriptive statistics of variables used in the analysis

\begin{tabular}{lrrrrr}
\hline Student level variables & Mean & \multicolumn{1}{c}{ SD } & \multicolumn{1}{c}{ Min. } & Max. & $\%$ \\
\hline Teacher expectations & 3.11 & 1.23 & 0.50 & 5.00 & \\
School leavers test & 532.72 & 10.27 & 501.00 & 550.00 & \\
Language test & 111.54 & 3.53 & 97.00 & 126.00 & \\
Mathematics test & 116.88 & 9.24 & 58.00 & 160.00 & \\
Reading comprehension test & 54.71 & 16.29 & 6.00 & 100.00 & \\
Social behavior & 3.63 & 0.79 & 1.00 & 5.00 & \\
Self-confidence & 3.81 & 0.74 & 1.00 & 5.00 & \\
Work habits & 3.42 & 0.88 & 1.00 & 5.00 & \\
Popularity & 3.62 & 0.79 & 1.00 & 5.00 & \\
Student-teacher relationship & 4.01 & 0.58 & 1.00 & 5.00 & \\
Gender & & & & & \\
Girls & & & & & \\
Boys & & & & & \\
Socio-ethnic background & & & & & \\
High SES & & & & & \\
Middle SES & & & & & \\
Low SES (Dutch) & & & & & \\
Low SES (Turkish/Morrocan) & & & & & \\
Low SES (other foreign) & & & & & \\
\hline
\end{tabular}


coded on a scale from 0.5 to 5 . This is considered an interval scale by assumption. According to the typology of measures of teachers' expectations by Hoge (1984), this operationalization can be seen as a global estimate of the student's academic potential, a one-dimensional index. This variable has been used in research before as the operationalization of teacher expectations (e.g. de Boer et al. 2010; Driessen 2006; Timmermans et al. 2015).

\subsubsection{School leavers test}

The students' scores on the school leavers test, which is developed by Cito, The Netherlands Institute for Educational Measurement, were available in the dataset. This is a high-stakes test administered in the final grade of Dutch primary education. Teachers regularly build their expectations on the results of this test. The test contains several parts, including the Dutch language (100 items), mathematics (60 items), and information processing (40 items). Students' scores are converted by Cito to a scale ranging from 501 to 550 .

\subsubsection{Tests from monitoring system}

The PRIMA cohort contains three tests that provide information on the performance of students during the final year of primary education. The tests used for this cohort were derived from the Cito Monitoring and Evaluation system and can be used by teachers to monitor the achievement and progress of their students. The language test consists of 64 items, the mathematics test consists of 120 items, and the reading comprehension test consists of 50 items. The scores used in the analyses are the scores on the underlying latent scales of language, mathematics, and reading comprehension as used in the monitoring system.

\subsubsection{Demographic characteristics of students}

A dummy variable was created for gender, where boys formed the reference group. Socio-ethnic background was a nominal variable with five categories based on the level of parental education and their ethnicity, indicating the combination of students' ethnicity and their parents' level of education. Three groups of students were defined based on parental education: low (prevocational education), middle (senior secondary education), and high (higher education or university). Only the students in the lowest category of parental education were split up further into three groups based on their ethnicity (Dutch, Turkish and Moroccan, ${ }^{1}$ and other foreign students). Only the category of low parental education was split up into further categories because there are considerably fewer students from non-Dutch parents in the middle and high parental education groups. For example, $74 \%$ of the students with a Turkish background and $79 \%$ of the students with a Moroccan background

\footnotetext{
1 Turkish and Moroccan students were selected in a separate category because they represent two large minority groups in the Netherlands that have developed since the 1960s. Previous research has shown that these groups behave rather similarly in the context of education.
} 
fall in the category of low educated parents. Students from the largest group formed the reference group in our analysis (middle parental education). Socio-ethnic status was included because previous research in the Netherlands has shown that low SES students tend to receive lower recommendations from their teachers (Claassen and Mulder 2003; De Boer et al. 2010; Timmermans et al. 2013).

\subsubsection{Social behavior of the student in the class}

Four items with five answer categories were included as part of the student profiles, measuring the teachers' perceptions of the students' social behavior in the classroom. A sample item is: "This student sticks to the class rules". The reliability of this scale is $\alpha=.83$. High scores on this variable indicate that a teacher perceives a student's classroom behavior as positive, while low scores indicate more negative teacher perceptions of the student's behavior.

\subsubsection{Student self-confidence}

Three items with five answer categories were included in the student profiles questionnaire, measuring the teachers' perceptions of students' self-confidence. A sample item is: "This student panics quickly". The reliability of this scale is $\alpha=.85$. High scores on this variable indicate that a teacher perceives the student as confident, while low scores indicate that the teacher perceives the student as less confident.

\subsubsection{Work habits}

Four items with five answer categories were included as part of the student profiles, measuring teachers' perceptions of students' work habits. A sample item from this scale is: "This student works accurately". The reliability of this scale is $\alpha=.81$. Similar to the previous perception variables, high scores reflect positively perceived work habits while lower scores reflect more negatively perceived work habits.

\subsubsection{Popularity}

Three items with five answer categories were included in the student profiles questionnaire, measuring teachers' perceptions of students' popularity in the class. A sample item is: "This student is popular among classmates." The reliability of this scale is $\alpha=.87$. The higher the score on this variable the more a teacher perceives a student as popular.

\subsubsection{Student-teacher relationship}

Four items with five answer categories were included as part of the student profiles, measuring teachers' perceptions of their relationships with the students. Sample 
items are: "This student has a good relationship with me (teacher)" and "This student feels comfortable with me (teacher)". The reliability of this scale is $\alpha=.86$. The higher the score on this variable the more positive a teacher is about the student-teacher relationship.

\subsection{Attrition analyses}

The analyses in this study were based on a selective subsample of complete cases. Differences were found between the students selected in the subsample and the students that were not selected due to missing values. On average, the performance of selected students was slightly higher than that of non-selected students (School leavers test $t=-4.38 ; d f=11.045 ; p<.001 ; d=.056$; language $t=-3.06$; $d f=11.770 ; p=.002 ; d=.042$; mathematics $t=-3.10 ; d f=11.809 ; p=.002$; $d=.033$; reading comprehension $t=-2.49 ; d f=11.669 ; p=.013 ; d=.039$ ). Furthermore, the selected students differed from the non-selected students based on their socio-ethnic background $\left(\chi^{2}=79.8 ; d f=4 ; p<.001\right)$ but not for gender $\left(\chi^{2}=0.34 ; d f=1 ; p=.56\right)$. Finally, with respect to the teacher perception variables, statistically significant differences were found only for work habits $(t=-3.41 ; \quad d f=8405 ; \quad p=.001 ; \quad d=.097) \quad$ and popularity $(t=-2.31 ;$ $d f=8440 ; p=.021 ; d=.048)$ with higher scores for the selected students than of the non-selected students. The results of this attrition analyses implies that the students included in the other analyses are not fully representative for Dutch students at the end of primary education and that results of this study cannot be generalized to the Dutch population without caution.

\subsection{Method of analysis}

The data had a hierarchical structure of students (level 1) nested within classes (level 2), and were analyzed using a two-level multilevel model (Snijders and Bosker 2012), using the MLwiN 2.28 software (Rasbash et al. 2009). The school level was not included in the models because most schools in the sample $(97.7 \%)$ had only one or two grade six classes, which was insufficient for an adequate distinction of variance between the class and the school level.

First, a multilevel model was estimated in which teacher expectations were used as the dependent variable and students' prior achievement and demographic background were included as predictor variables (Model 1). In Model 2, variables concerning the teachers' perceptions of students' classroom behavior were included in the multilevel model as predictors of teacher expectations (research questions 1 and 2). Furthermore, a model was estimated in which random slopes were allowed for the teacher-perception variables (Model 3, research question 3). In the final model, interactions between student performance (school leavers test) and teacherperception variables were included as predictors of expectations (research question 4). All continuous variables in the analyses were standardized in order to obtain estimates that could be compared between variables in the same model. 


\section{Results}

\subsection{Correspondence between teachers' expectations, perceptions and student performance}

In Table 2, the zero-order correlations are presented among the expectations of teachers, the previous academic performance of students, and the teachers' perceptions of students' classroom behavior. The strongest association was found between the teachers' expectations and the performance of students on the school leavers test $(r=.88)$. Somewhat lower yet strong correlations were found between the expectations of teachers and the scores of students in the monitoring system (language $r=.65$; mathematics $r=.74$; reading comprehension $r=.76$ ). A modest correlation was found between teacher expectations and teachers' perceptions of students' work habits $(r=.42)$. Lower but still statistically significant correlations were found between teacher expectations and the other perceptions of classroom behavior (self-confidence $r=.20$; popularity $r=.16$; social behavior $r=$ .20 ; student-teacher relationship $r=.15$ ). Among the teacher-perception variables, the strong association between the perceived social behavior of students in the classroom and perceived work habits $(r=.58)$ stands out.

\subsection{Multilevel models for the association between teacher expectations and perceptions}

The results of the various multilevel models are presented in Table 3. In the baseline model (Model 1), the students' prior achievement and demographic background were included as predictors of the teachers' expectations. From this model it appeared that the teachers' expectations for an average student is 3.07, which corresponds to a recommendation for the theoretical track of pre-vocational education. Of the remaining unexplained variance, $20.7 \%$ is related to the class level. This indicates that there are substantial differences among teachers in their recommendations for students with equal background and equal records of prior achievement. The findings from this baseline model also suggest that teacher expectations are related to the socio-ethnic background and gender of students. On average, teachers have lower expectations of low-SES students, regardless of their ethnicity, and of boys.

In Model 2 (Table 3), the teachers' perceptions of students' classroom behavior were included in the model as predictors of teacher expectations. The teachers' perceptions of students' self-confidence, work habits, and social behavior in the classroom are statistically significant predictors of teacher expectations, after students' prior achievement and background are controlled for. The strongest relation was found between teachers' expectations and teachers' perceptions of students' work habits, which is not surprising, given the moderately strong correlation found in Table 2. On average, teachers give somewhat higher recommendations for secondary education to students whom they perceive as having higher self-confidence or more positive work habits. Furthermore, although 


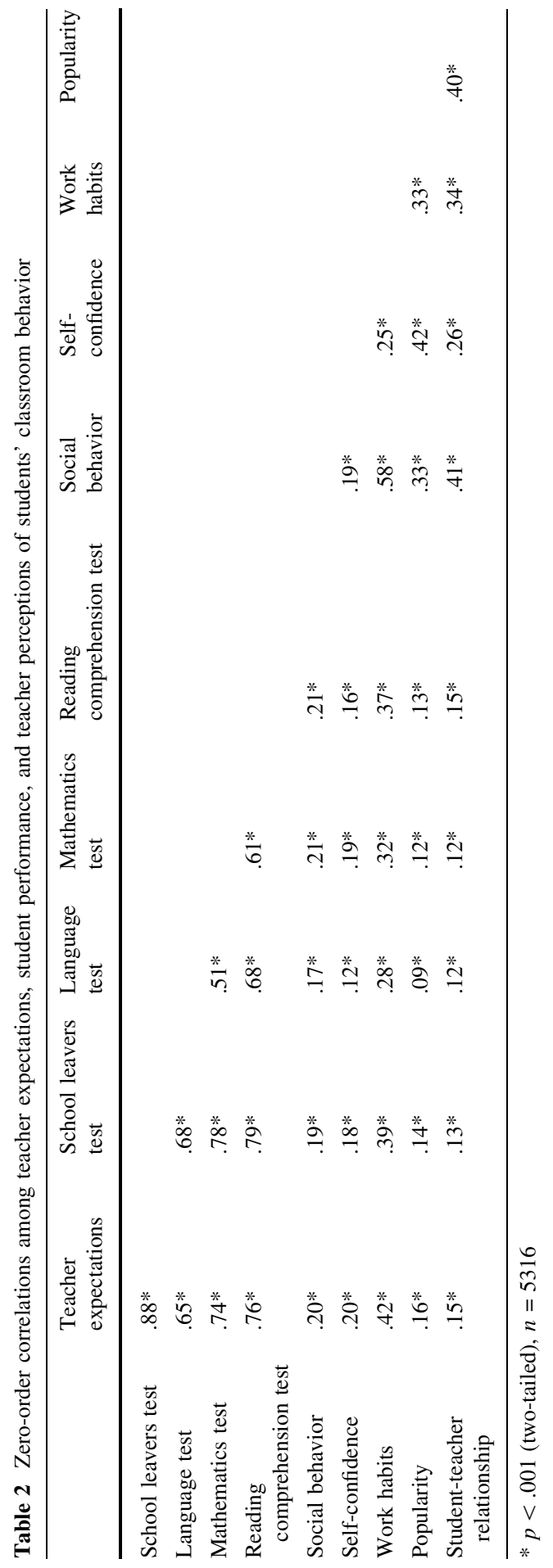


Table 3 Results of the multilevel regression analysis

\begin{tabular}{|c|c|c|c|c|c|c|c|c|}
\hline & \multicolumn{2}{|c|}{ Model 1} & \multicolumn{2}{|c|}{ Model 2} & \multicolumn{2}{|c|}{ Model 3} & \multicolumn{2}{|c|}{ Model 4} \\
\hline & $\beta$ & $\operatorname{SE}(\beta)$ & $\beta$ & $\operatorname{SE}(\beta)$ & $\beta$ & $\operatorname{SE}(\beta)$ & $\beta$ & $\operatorname{SE}(\beta)$ \\
\hline \multicolumn{9}{|l|}{ Fixed part } \\
\hline \multicolumn{9}{|l|}{ Student-level variables } \\
\hline Intercept & 3.07 & $(0.02)^{*}$ & 3.10 & $(0.02)^{*}$ & 3.10 & $(0.02)^{*}$ & 3.09 & $(0.02)^{*}$ \\
\hline School leavers test & 0.80 & $(0.02)^{*}$ & 0.78 & $(0.02)^{*}$ & 0.78 & $(0.02)^{*}$ & 0.78 & $(0.02)^{*}$ \\
\hline Language test & 0.07 & $(0.01)^{*}$ & 0.07 & $(0.01)^{*}$ & 0.07 & $(0.01)^{*}$ & 0.07 & $(0.01)^{*}$ \\
\hline Mathematics test & 0.20 & $(0.01)^{*}$ & 0.18 & $(0.01)^{*}$ & 0.18 & $(0.01)^{*}$ & 0.17 & $(0.01)^{*}$ \\
\hline Reading comprehension test & 0.11 & $(0.01)^{*}$ & 0.10 & $(0.01)^{*}$ & 0.10 & $(0.01)^{*}$ & 0.10 & $(0.01)^{*}$ \\
\hline Gender (girls) & 0.10 & $(0.01)^{*}$ & 0.05 & $(0.02)^{*}$ & 0.05 & $(0.02)^{*}$ & 0.05 & $(0.02)^{*}$ \\
\hline $\begin{array}{l}\text { Low SES Turkish or } \\
\text { Moroccan }\end{array}$ & -0.06 & $(0.03)^{*}$ & -0.07 & $(0.03)^{*}$ & -0.07 & $(0.02)^{*}$ & -0.07 & $(0.02)^{*}$ \\
\hline Low SES other foreign & -0.07 & $(0.03)^{*}$ & -0.08 & $(0.03)^{*}$ & -0.08 & $(0.03)^{*}$ & -0.08 & $(0.03)^{*}$ \\
\hline Low SES Dutch & -0.11 & $(0.02)^{*}$ & -0.10 & $(0.02)^{*}$ & -0.10 & $(0.02)^{*}$ & -0.10 & $(0.02)^{*}$ \\
\hline High SES & 0.09 & $(0.02)^{*}$ & 0.09 & $(0.02)^{*}$ & 0.09 & $(0.02)^{*}$ & 0.09 & $(0.02)^{*}$ \\
\hline Self-confidence & & & 0.02 & $(0.01)^{*}$ & 0.02 & $(0.01)^{*}$ & 0.02 & $(0.01)^{*}$ \\
\hline Work habits & & & 0.10 & $(0.01)^{*}$ & 0.10 & $(0.01)^{*}$ & 0.10 & $(0.01)^{*}$ \\
\hline Popularity & & & 0.01 & $(0.01)$ & 0.01 & $(0.01)$ & 0.004 & $(0.01)$ \\
\hline Social behavior & & & -0.03 & $(0.01)^{*}$ & -0.03 & $(0.01)^{*}$ & -0.03 & $(0.01)^{*}$ \\
\hline $\begin{array}{l}\text { Student-teacher } \\
\text { relationship }\end{array}$ & & & 0.004 & $(0.01)$ & 0.003 & $(0.01)$ & 0.001 & $(0.01)$ \\
\hline \multicolumn{9}{|l|}{ Interaction variables } \\
\hline $\begin{array}{l}\text { School leavers test } * \text { self- } \\
\text { confidence }\end{array}$ & & & & & & & 0.002 & $(0.01)$ \\
\hline $\begin{array}{l}\text { School leavers test * work } \\
\text { habits }\end{array}$ & & & & & & & 0.03 & $(0.01)^{*}$ \\
\hline $\begin{array}{l}\text { School leavers test * } \\
\text { popularity }\end{array}$ & & & & & & & -0.01 & $(0.01)$ \\
\hline $\begin{array}{l}\text { School leavers test * social } \\
\text { behavior }\end{array}$ & & & & & & & 0.004 & $(0.01)$ \\
\hline $\begin{array}{l}\text { School leavers test * } \\
\text { student-teacher } \\
\text { relationship }\end{array}$ & & & & & & & -0.02 & $(0.01)^{*}$ \\
\hline \multicolumn{9}{|l|}{ Random part } \\
\hline $\begin{array}{l}\text { Teacher-level intercept } \\
\text { variance }\end{array}$ & 0.06 & $(0.01)$ & 0.06 & $(0.01)$ & 0.06 & $(0.01)$ & 0.06 & $(0.01)$ \\
\hline $\begin{array}{l}\text { Teacher-level slope } \\
\text { variance self-confidence }\end{array}$ & & & & & 0.002 & $(0.002)$ & 0.002 & $(0.002)$ \\
\hline $\begin{array}{l}\text { Teacher-level slope } \\
\text { variance work habits }\end{array}$ & & & & & 0.003 & $(0.002)$ & 0.003 & $(0.002)$ \\
\hline
\end{tabular}


Table 3 continued

\begin{tabular}{|c|c|c|c|c|c|c|c|c|}
\hline & \multicolumn{2}{|c|}{ Model 1} & \multicolumn{2}{|c|}{ Model 2} & \multicolumn{2}{|c|}{ Model 3} & \multicolumn{2}{|c|}{ Model 4} \\
\hline & $\beta$ & $\operatorname{SE}(\beta)$ & $\beta$ & $\operatorname{SE}(\beta)$ & $\beta$ & $\operatorname{SE}(\beta)$ & $\beta$ & $\operatorname{SE}(\beta)$ \\
\hline $\begin{array}{l}\text { Teacher-level slope } \\
\text { variance social behavior }\end{array}$ & & & & & 0.001 & $(0.002)$ & 0.001 & $(0.002)$ \\
\hline $\begin{array}{l}\text { Teacher-level slope variance } \\
\text { student-teacher relationship }\end{array}$ & & & & & 0.001 & $(0.002)$ & 0.001 & $(0.002)$ \\
\hline $\begin{array}{l}\text { Student-level intercept } \\
\text { variance }\end{array}$ & 0.23 & $(0.01)$ & 0.22 & $(0.004)$ & 0.22 & $(0.01)$ & 0.22 & $(0.01)$ \\
\hline \multicolumn{9}{|l|}{ Model fit } \\
\hline$-2 *$ log-likelihood & \multicolumn{2}{|c|}{7833.24} & \multicolumn{2}{|c|}{7706.69} & \multicolumn{2}{|c|}{7677.16} & \multicolumn{2}{|c|}{7655.02} \\
\hline Number of classes & \multicolumn{2}{|l|}{469} & \multicolumn{2}{|l|}{469} & \multicolumn{2}{|l|}{469} & \multicolumn{2}{|l|}{469} \\
\hline Number of students & \multicolumn{2}{|l|}{5316} & \multicolumn{2}{|l|}{5316} & \multicolumn{2}{|l|}{5316} & \multicolumn{2}{|l|}{5316} \\
\hline
\end{tabular}

$* p<.05$

the difference is relatively small, teachers tend to give somewhat lower recommendations to students for whom they perceive good social behavior in the classroom, all other characteristics being equal. Together, these teacher-perception variables explained $3 \%$ of the variance in teacher expectations on top of the performance variables.

The second research question pertained to the extent to which teachers' perceptions of students' classroom behavior can account for differences found in teachers' expectations for various demographic subgroups of students. When teacher-perception variables were included, almost all other coefficients in the multilevel model remained the same, with the exception of the coefficient for gender. The difference in teacher expectations between boys and girls decreased, which implies that one of the reasons why girls received higher recommendations from teachers is that the teachers also had more positive perceptions of girls' classroom behavior. In this sample, statistically significantly more positive teacher perceptions were found for girls with respect to work habits $(t=-22.06$; $d f=$ 5247.24; $p<.001)$, popularity $(t=-4.77 ; d f=5311.31 ; p<.001)$, social behavior $(t=-16.49 ; d f=5266.09 ; p<.001)$, and student-teacher relationship $(t=-8.52 ; d f$ $=5293.75 ; p<.001)$, but not for self-confidence $(t=0.96 ; d f=5312.99 ; p=.340)$.

Because the results from Model 2 partly contradicted those of previous research, we estimated separate models for each of the teacher-perception variables. The results of these analyses are presented in Table 4. Statistically significant positive associations were found for each of the perception variables when they were investigated separately. Again, work habits seem to have the strongest association with teacher expectations. Furthermore, it appears that the reduction of the differences between boys and girls is primarily due to the inclusion of teachers' perceptions of students' work habits. 


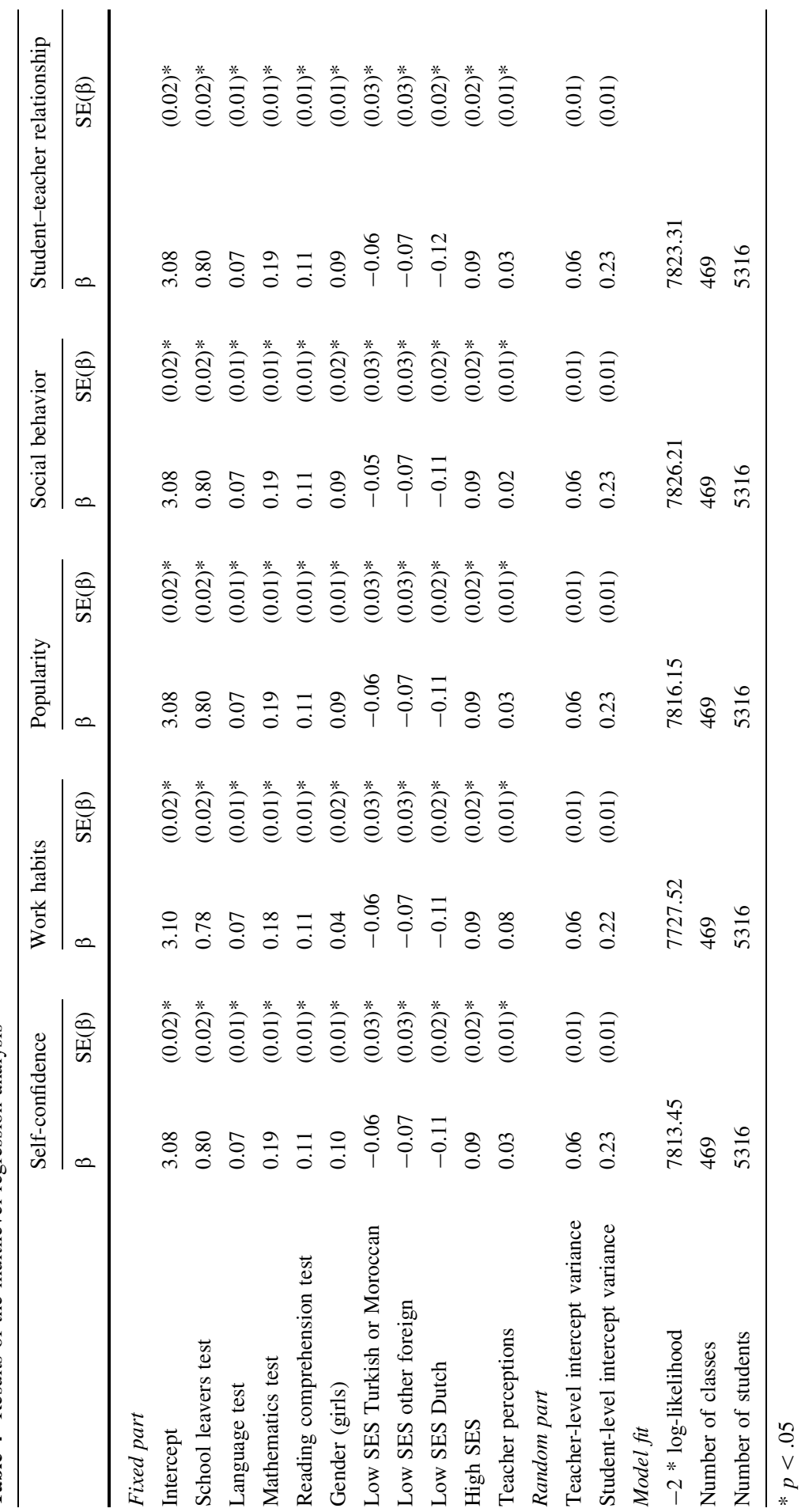




\subsection{Between-class differences in association between teacher expectations and perceptions}

The third research question pertained to differences among teachers in the association between expectations and perceptions of students' classroom behavior. Random slopes were allowed for the teacher-perception variables to test differences between teachers (Model 3, Table 3). Including random slopes for the teacherperception variables of self-confidence, work habits, social behavior, and studentteacher relationship led to a statistically significant increase of the model fit $\left(\chi^{2}=\right.$ 29.53, $d f=14 ; p=.009$ ); however, including random slopes for the teachers' perceptions of popularity did not lead to an improved model fit. Differences among teachers with respect to the random slopes of teacher perceptions are presented in Fig. 1.

For all teachers, positive associations were found between perceived work habits and expectations of students, although the expectations of some teachers are more strongly shaped by their perceptions of students' work habits than others [range 0.03-0.19]. With respect to the teachers' perceptions of students' self-confidence, both positive and negative associations [range -0.05 to 0.09 ] with expectations were found, although in general teachers tended to have higher expectations for students whom they perceived as more confident. When all teachers were

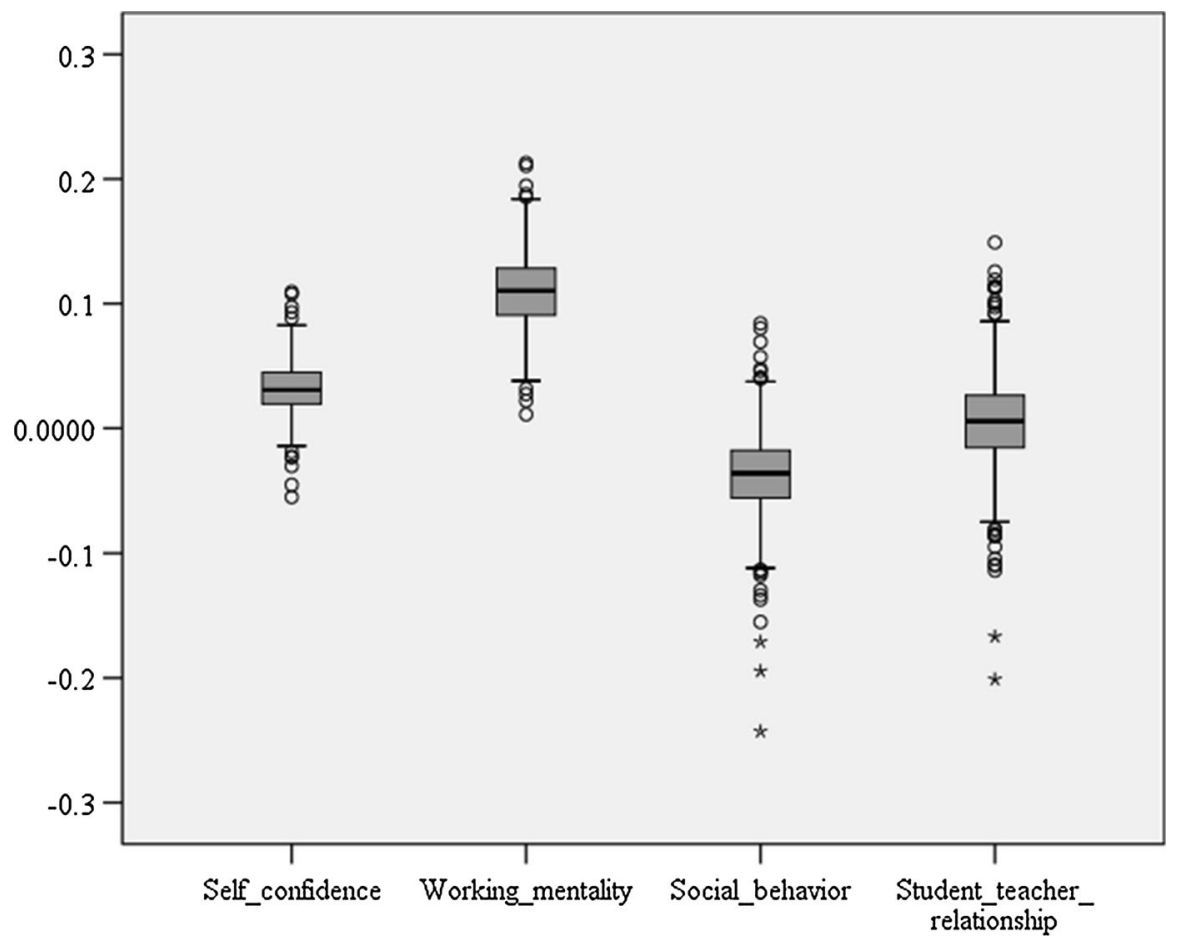

Fig. 1 Differences among teachers in the association between perceptions and expectations 
considered together, a small negative association was found between teachers' expectations and their perceptions of students' social behavior $(\beta=-0.03)$; however, this association was heterogeneous [range -0.19 to 0.07]. A small proportion of teachers had a positive association between their perceptions of students' social behavior and their expectations, while a larger proportion of teachers showed negative associations between their expectations and their perceptions of social behavior. Finally, although we did not find evidence for a general association between teachers' perceptions of the student-teacher relationship and their expectations $(\beta=0.003)$, considerable differences among teachers were found [range -0.13 to 0.09 ].

\subsection{Achievement-dependent association between teachers' expectations and perceptions}

The fourth research question refers to the possible dependence of the relationship between teacher expectations and teacher perceptions on the performance level of the students. In Model 4 (Table 3), interactions were included between students' performance, as measured on the school leavers test, and teachers' perceptions of classroom behavior. For two of the five teacher-perception variables, small but statistically significant interactions were found with students' performance. A statistically significant positive interaction was found between student performance and teachers' perceptions of students' work habits. This indicates that the differences in expectations between students whose teachers had high or low perceptions of their work habits are greater for high-performing students than for low-performing students. A negative interaction was found between the performance of students and teachers' perceptions of the student-teacher relationship, indicating that the differences in expectations among students whose teachers had high or low perceptions of the student-teacher relationship are more pronounced for students with low performance levels. We did not find evidence for interaction effects between student performance and teachers' perceptions of students' selfconfidence, popularity, and social behavior. This implies that the associations between teachers' expectations and teachers' perceptions of students' selfconfidence are relatively independent of the students' performance levels.

\section{Conclusion and discussion}

Although several researchers have pointed to a gap in knowledge on the relationship among teacher expectations and student attributes other than their demographic background (Hecht and Greenfield 2002; Hughes et al. 2005; Rubie-Davies 2010), a lack of empirical evidence remains. The aim of the present study was to contribute to knowledge on the issue why for some students the expectations of teachers do not correspond with students' performance. In this study we investigated both differences between teachers and a wide range of teacher perceptions including working habits, popularity, self-confidence, student-teacher relationships, and 
classroom behavior. A large-scale database of 5316 students and 469 classes in Dutch primary education was investigated.

The results of this study indicated that teachers' expectations for the future academic performance of their students during the final grade of primary school were related to several teacher perceptions of student attributes. In general, teachers had higher expectations for a student if they perceived the student as self-confident and having positive work habits, which is in line with previous research on the association between teacher expectations and perceptions (Alvridez and Weinstein 1999; Bonvin and Genoud 2006; Driessen 2006). This finding may indicate that primary school teachers consider positive working habits and being self-confident as important student attributes for being successful in the higher tracks of Dutch secondary education. On the other hand, teachers appeared to have lower expectations for students whom they perceived as exhibiting more positive social behavior in the classroom, which contradicts findings from previous research (Bennet et al. 1993; Hecht and Greenfield 2002; Kelly and Carbonaro 2012; LaVoie and Adams 1973), where it was concluded that teachers on average had higher expectations for students with good conduct. Contrary to our expectations, we did not find evidence for a relationship between teachers' expectations for students' future academic performance and teachers' perceptions of the student-teacher relationship after several performance measures and other perceptions were controlled for. A possible explanation for this finding is that some classes might have had part-time teachers and in that case, the expectations in this study could be considered the shared expectations of the teachers of a student. The teacher-student relationship of a particular student may differ between several teachers.

All in all, the combined teacher-perception variables of student attributes explained $3 \%$ of the variance in teacher expectations on top of student performance. Given that student performance already explained $80 \%$ of the variance in expectations, the $3 \%$ additional explained variance can be considered as a considerable amount. The current study deviates from many of the previous studies because we investigated several teacher perceptions simultaneously, whereas many other studies have looked at single aspects of teacher perceptions. Additional analyses, using separate multilevel models per teacher-perception variable, indicated that the simultaneous analysis of all perception variables may explain why the current results only partly correspond to previous findings. Given that the various aspects of teacher perceptions are interrelated, a simultaneous assessment of teacher perceptions might be more informative and result in better estimates of the unique associations among teacher perceptions and expectations.

What classroom behaviors of students are considered important by teachers for future educational success may depend on the performance levels of the students (Lane et al. 2006). We found that teachers' perceptions of the students' work habits are more important for high-performing students, while the perceived studentteacher relationship appears to be more important for low-performing students. These findings may also imply that primary school teachers consider different student attributes to be important to succeed in different tracks in secondary education, with good working habits to be more important in the higher more demanding tracks, and being able to establish positive teacher-student relationships 
in the lower tracks. This and the previous findings imply that student performance and other student attributes are somehow equated in the minds of teachers (Hoge 1984) when making inferences on the students' future performance.

Second, we found that the difference in teacher expectations between boys and girls decreased following the inclusion of teacher perceptions of students' classroom behavior in the model. The results from the separate models for each perception variable indicate that the decrease of the difference in teacher expectations between boys and girls is primarily due to the teachers' perceptions of the students' work habits. There may be two explanations for these results. First, the well-documented difference in teacher expectations between boys and girls (e.g., de Boer et al. 2010, Ready and Wright 2011; Rubie-Davies 2008; Timmermans et al. 2015) is only a partly true gender bias, but stems from differences between boys and girls in actual behavior that is reflected in the teachers' perceptions of student attributes. Second, it may still be "gender bias" if teachers base their expectations of boys and girls on how they perceive them to behave rather than on their actual behavior in the classroom. Previous findings indicate that teachers do have different perceptions of boys and girls and, on some occasions, this did influence teachers' decisions regarding achievement levels (Riley 2014). Consistent with the current study, female students are generally perceived by their teachers as working harder and producing higher quality work (Bennet et al. 1993; Reyna 2000; Siegle and Reis 1994). In the current study we did not have any other objective indicator of the student attributes and classroom behavior, therefore it was not possible to investigate which of the two explanations was the most likely. Differences in expectations between high- and low-SES students, on the other hand, did not change following the inclusion of teacher-perception variables.

The third research question was focused on the differences among teachers, both in their expectations and in the extent to which they let their perceptions of classroom behavior shape their expectations. After students' prior achievement was controlled for, $20.7 \%$ of the unexplained variance in teacher expectations was associated with the class level, which corresponds to previous research findings in the Netherlands (de Boer et al. 2010; Van den Bergh et al. 2010). Furthermore, the results of the current study suggest that there are considerable differences between teachers in the extent to which they let their perceptions of students' selfconfidence, work habits, social behavior, and student-teacher relationship shape their expectations of the students' future academic performance. All teachers in the sample seemed to let the perceived work habits of the student positively shape their expectations, although the expectations of some teachers were more strongly shaped in this way than others. For the teachers' perceptions of students' self-confidence, social behavior, and student-teacher relationships, it was found that they shaped the expectations of some teachers positively, while it shaped the expectations of other teachers negatively.

\subsection{Limitations}

In interpreting the results of this study a number of limitations need to be considered. First, we investigated differences among groups of students in teacher 
expectations following the conditional neutrality position (Ferguson 1998, 2003), thus after taking the student past and current performance into account. Therefore, the results derived from the estimated models can only be interpreted in the contexts of the two sources of performance information available: the school leavers test and achievement tests from the schools' monitoring systems. Second, the cross sectional nature of this large-scale dataset does not permit any conclusions regarding causal pathways between perceptions of students' classroom behavior and teacher expectations. Consistent with transactional models of development, it can be expected that teachers' expectations for the future performance of students and the student-teacher relationship influence each other in a reciprocal fashion (Hughes et al. 2005). Similarly, reciprocal relationships might exist between teachers' expectations and the other perceptions of students' attributes included in this study. Analysis of the relationships between teacher perceptions and teacher expectations should preferably be done using longitudinal data, which include information on every year's scores on these aspects. In this way, their transactional character may be investigated. Third, information on teacher's expectations and their perceptions of student classroom behavior were both based on the teacher reports. As a result, it may be likely that mono-method bias in measuring expectations and perceptions accentuated the relations among these variables. The teacher reports also did not allow us to distinguish between the perceptions of teachers and the actual behavior of the students. Finally, although the data allowed us to identify which students attended the same classes, we could not be completely certain whether the class level was identical to the teacher level in all cases. Some classes may have had parttime teachers, in which case some expectations in this study might have been shared ones.

\subsection{Recommendations for future research}

Given the number of limitations, the results of the current study open important pathways for future research into the question: "What are the relations between teachers' perceptions of current attributes of pupils and their expectations for the future performance of the pupils?" (Hoge 1984, p. 216). Two findings from this study may be of particular interest for more in-depth investigations.

The first finding was that the difference in the expectations of teachers for boys and girls decreased considerably when the teachers' perceptions of student attributes were included in the model. There are two possible explanations for this finding that we could not disentangle given the design of this current study. Future research may benefit from including observational data of the students' behavior in the classroom as these data may help to investigate whether biased teacher expectations stem from biased perceptions of student attributes or from a different behavior reflected in valid perceptions of student attributes. In the current study, the teachers' perceived female students as behaving better than their male counterparts. How much of this difference is based on perception and how much of this is based on actual classroom behaviour?

The second finding relates to the relatively large differences between teachers in the extent and direction to which they let their perceptions of students' attributes 
shape their expectations of the students' future academic performance. This finding suggests that there is no one answer to the question of what is the association between the expectations and perceptions of attributes, as this association differs per teacher. For future research it would be interesting to investigate the extent to which the teachers' personal values influence their perceptions of students. For example, do teachers who place a higher value on attributes like "self-confidence" or "work habits" expect more from students who they perceive as exhibiting those qualities than students who they do not perceive as exhibiting those qualities? Are there certain teachers who are more likely than others to be influenced by their perceptions when it comes to formulating expectations for their students? And if that is the case, why is that?

Naturalistic studies such as this one, are, despite their limitations, important because they strengthen the ecological validity of findings and provide an ethically sound way to explore negative teacher expectations (Alvridez and Weinstein 1999). All in all, the current findings add to the literature not only by providing evidence on the relationship between teacher expectations and perceptions of student behavior (Bennet et al. 1993; Hecht and Greenfield 2002), but also by showing that this association is rather complex due to differences among teachers and dependence on students' performance levels. Further investigation of the association between perceptions and expectations may be needed, as perceptions and expectations may sometimes be inaccurate (Lane et al. 2006; MacLure et al. 2012) and both may influence teacher behavior and the subsequent performance of students (e.g., Bennet et al. 1993; Brophy and Good 1970; Hamre and Pianta 2006; Ready and Wright 2011; Rubie-Davies 2007, 2008, 2010).

Whether teachers' perceptions of students' attributes can be considered relevant or irrelevant to the shaping of teachers' expectations is a matter of debate (Bennet et al. 1993). This depends mainly on how the concept of teachers' expectations is defined. The association between perceptions of classroom behavior and expectations can be considered a threat to the validity of teacher expectations when teacher expectations are assumed to include only the future academic performance of students. It is somewhat different if teacher expectations are assumed to be based not only on cognitive, but also on non-cognitive aspects. Especially in the context of the transition from primary to secondary education, a number of student attributes may be seen as valid sources for teacher expectations. Besides cognitive abilities, having a positive working habit may help students to succeed and to adapt to different demands and methods during secondary education. However, this could still be detrimental to certain groups of students if it is found that some teachers have more of a tendency to perceive certain groups of students as "inherently" having particular attributes such as "good behavior", "solid work ethic", or being "socially adaptable". Depending on whether teacher perceptions of student attributes are considered relevant sources of variation, the finding of differences among teachers may have important consequences for the development of interventions or tools to improve the accuracy of teacher expectations. 
Open Access This article is distributed under the terms of the Creative Commons Attribution 4.0 International License (http://creativecommons.org/licenses/by/4.0/), which permits unrestricted use, distribution, and reproduction in any medium, provided you give appropriate credit to the original author(s) and the source, provide a link to the Creative Commons license, and indicate if changes were made.

\section{References}

Alvridez, J., \& Weinstein, R. S. (1999). Early teacher perceptions and later student academic achievement. Journal of Educational Psychology, 91, 731-746. doi:10.1037/0022-0663.91.4.731.

Bennet, R. A., Gottesman, R. L., Rock, D. A., \& Cerullo, F. (1993). Influence of behavior perceptions on teachers' judgments of students' academic skill. Journal of Educational Psychology, 85, 347-356. doi:10.1037/0022-0663.85.2.347.

Bonvin, P., \& Genoud, P. A. (2006). Teacher perceptions of student characteristics: "Halo effects" between behavioural and social perceptions, and expectations for academic achievement. Paper presented at European Conference on Educational Research (ECER), Geneva, September 2006.

Brophy, J. E., \& Good, T. L. (1970). Teachers' communication of differential expectations for children's classroom performance: Some behavioral data. Journal of Educational Psychology, 61, 365-374.

Brophy, J. E., \& Good, T. L. (1974). Teacher-student relationships: Causes and consequences. NewYork: Holt, Rinehart \& Winston.

Claassen, A., \& Mulder, L. (2003). Leerlingen na de overstap. Een vergelijking van vier cohorten leerlingen na de overgang van basisonderwijs naar voortgezet onderwijs met nadruk op de positie van doelgroepleerlingen in het onderwijsachterstanden beleid. [Students after the transition. A comparison of four student cohorts after the transition from primary to secondary education with a specific focus on the position of at risk students]. Nijmegen: ITS, Radboud Universiteit Nijmegen.

Cooper, H., Findley, M., \& Good, T. (1982). Relations between student achievement and various indexes of teacher expectations. Journal of Educational Psychology, 74, 570-577. doi:10.1037/0022-0663. 74.4.577.

de Boer, H., Bosker, R. J., \& van der Werf, M. P. C. (2010). Sustainability of teacher expectation bias effects on long-term student performance. Journal of Educational Psychology, 102, 168-179. doi:10.1037/a0017289.

Driessen, G. (2005). De totstandkoming van de adviezen voortgezet onderwijs: invloeden van thuis en school. [The realization of track recommendations; influences from home and school]. Pedagogiek, 25, 279-298.

Driessen, G. (2006). Het advies voortgezet onderwijs: Is de overadvisering over? [Track recommendations for secondary education: The end of low track recommendations?]. Mens en Maatschappij, 81, 1.

Driessen, G. (2011). Onderadvisering van allochtone leerlingen? [Low track recommendations for minority students?]. Nijmegen: ITS, Radboud Universiteit Nijmegen.

Driessen, G., Langen, A. van, \& Vierke, H. (2006). Basisonderwijs: Veldwerkverslag, leerlinggegevens en oudervragenlijsten. Basisrapportage PRIMA-cohortonderzoek. Zesde meting 2004/05. [Primary education: Data collection report for student data and parent questionnaires. Report PRIMA cohort study, sixth wave 2004/2005]. Nijmegen: ITS.

Ferguson, R. F. (1998). Teachers' perceptions and expectations and the black-white test score gap. In C. Jencks \& M. Philips (Eds.), The black-white test score gap (pp. 273-317). Washington: Brookings Institution Press.

Ferguson, R. F. (2003). Teachers' perceptions and expectations and the black-white test score gap. Urban Education, 38, 460-507. doi:10.1177/0042085903254970.

Glock, S., \& Krolak-Schwerdt, S. (2013). Does nationality matter? The impact of stereotypical expectations of student teachers' judgments. Social Psychology of Education, 16, 111-127.

Good, T. L. (1987). Two decades of research on teacher expectations: Findings and future directions. Journal of Teacher Education, 38, 32-47. doi:10.1177/002248718703800406.

Hamre, B. K., \& Pianta, R. C. (2006). Student-teacher relationships. In G. Bear \& K. Minke (Eds.), Children's needs III: Development, prevention, and intervention (pp. 59-71). Washington: National Association of School Psychologists. 
Hecht, S. A., \& Greenfield, D. B. (2002). Explaining the predictive accuracy of teacher judgments of their students' reading achievement: The role of gender, classroom behavior, and emergent literacy skills in a longitudinal sample of children exposed to poverty. Reading and Writing: An Interdisciplinary Journal, 15, 789-809. doi:10.1023/A:1020985701556.

Helwig, R., Anderson, L., \& Tindal, G. (2001). Influence of elementary student gender on teachers' perceptions of mathematics achievement. The Journal of Educational Research, 95, 93-102. doi:10. 1080/00220670109596577.

Hinnant, J. B., O’Brien, M., \& Ghazarian, S. R. (2009). The longitudinal relations of teacher expectations to achievement in the early school years. Journal of Educational Psychology, 101, 662-670. doi:10. 1037/a0014306.

Hoge, R. B. (1984). The definition and measurement of teacher expectations: Problems and prospects. Canadian Journal of Education, 9, 213-228. doi:10.2307/1494604.

Hughes, J. N., Gleason, K. A., \& Zhang, D. (2005). Relationship influences on teachers' perceptions of academic competence in academically at-risk minority and majority first grade students. Journal of School Psychology, 43, 303-320.

Inspectorate of Education (2007). Teacher recommendations in the picture. [Onderadvisering in beeld]. Utrecht: Inspectorate of Education.

Inspectorate of Education (2014). De staat van het onderwijs. Onderwijsverslag 2012/2013. [The state of education in the Netherlands. Report 2012/2013]. Utrecht: Inspectie van het Onderwijs.

Jussim, L., Eccles, J., \& Madon, S. (1996). Social perception, social stereotypes, and teacher expectations: Accuracy and the quest for the powerful self-fulfilling prophecy. In M. P. Zanna (Ed.), Advances in experimental social psychology (Vol. 28, pp. 281-388). San Diego, New York: Academic Press.

Jussim, L., \& Harber, K. D. (2005). Teacher expectations and self-fulfilling prophecies: Knowns and unknowns, resolved and unresolved controversies. Personality and Social Psychology Review, 9, $131-155$.

Kelly, S., \& Carbonaro, W. (2012). Curriculum tracking and teacher expectations: Evidence form discrepant course taking models. Social Psychology of Education, 15, 271-294. doi:10.1007/ s11218-012-9182-6.

Lane, K. L., Wehby, J. H., \& Cooley, C. (2006). Teacher expectations of students' classroom behavior across the grade span: Which social skills are necessary for success? Exceptional Children, 72, $153-167$.

LaVoie, J. C., \& Adams, G. R. (1973). Pygmalion in the classroom: An experimental investigation of the characteristics of children in teacher expectancy. Paper presented at the annual meeting of the Midwest Psychological Association. Chicago, Illinois, may 1973

MacLure, M., Jones, L., Holmes, R., \& MacReau, C. (2012). Becoming a problem: Behaviour and reputation in the early years classroom. British Educational Research Journal, 38, 447-471. doi:10. 1080/01411926.2011.552709.

Madon, S., Willard, J., Guyll, M., \& Scherr, K. C. (2011). Self-fulfilling prophecies: Mechanisms, power and links to social problems. Social and Personality Psychology Compass, 5, 578-590. doi:10.111/j. 1751-9004.2001.00375.x.

McKnown, C., \& Weinstein, R. S. (2008). Teacher expectations, classroom context, and the achievement gap. Journal of School Psychology, 46, 235-261. doi:10.1016/j.jsp.2007.05.001.

Merton, R. K. (1948). The self-fulfilling prophecy. The Antioch Review, 8, 193-210.

Ministry of Education. (2014). Key-figures 2009-2013: Education, culture, science. DenHaag: Ministry of Education.

Rasbash, J., Charlton, C., Browne, W. J., Healy, M., \& Cameron, B. (2009). MLwiN version 2.1. Bristol: Centre for Multilevel Modelling, University of Bristol.

Ready, D. D., \& Wright, D. L. (2011). Accuracy and inaccuracy in teachers' perceptions ofyoung children's cognitive abilities the role of child background and classroom context. American Educational Research Journal, 48, 335-360. doi:10.3102/0002831210374874.

Reyna, C. (2000). Lazy, dump, or industrious: When stereotypes convey attribution information in the classroom. Educational Psychology Review, 12, 85-110.

Riley, T. (2014). Boys are like puppies, girls aim to please: How teachers' gender stereotypes may influence student placement decisions and classroom teaching. Alberta Journal of Educational Research, 60(1), 1-21. 
Riley, T., \& Ungerleider, C. (2012). Self-fulfilling prophecy: How teachers' attributions, expectations, and stereotypes influence the learning opportunities afforded Aboriginal students. Canadian Journal of Education, 35, 303-333.

Rosenthal, R., \& Jacobsen, L. (1968). Pygmalion in the classroom: Teacher expectations and pupil's intellectual development. New York: Holt, Rinehart \& Winston.

Rubie-Davies, C. M. (2007). Classroom interactions: Exploring practices of high- and low-expectation teachers. British Journal of Educational Psychology, 77, 289-306. doi:10.1348/ $000709906 \times 101601$.

Rubie-Davies, C. M. (2008). Teacher expectations. In T. Good (Ed.), 21st century education: A reference handbook (pp. I-254-I-265). Thousand Oaks: SAGE Publications. doi:10.4135/9781412964012.n27.

Rubie-Davies, C. M. (2010). Teacher expectations and perceptions of student attributes: Is there a relationship? British Journal of Educational Psychology, 80, 121-135. doi:10.1348/ 000709909 X466334.

Rubie-Davies, C. M., Hattie, J., \& Hamilton, R. (2006). Expecting the best for students: Teacher expectations and academic outcomes. British Journal of Educational Psychology, 76, 429-444. doi: 10.1348/000709905X53589.

Siegle, D., \& Reis, S. M. (1994). Gender differences in teacher and student perceptions of student ability and effort. The Journal of Secondary Gifted Education, 6, 86-92.

Snijders, T. A. B., \& Bosker, R. J. (2012). Multilevel analysis: An introduction to basic and advanced multilevel modeling (2nd ed.). London/Thousand Oaks/New Delhi: Sage Publications Ltd.

Sorhagen, N. S. (2013). Early teacher expectations disproportionately affects poor children's high school performance. Journal of Educational Psychology, 105, 465-477. doi:10.1037/a0031754.

Speybroeck, S., Kuppens, S., van Damme, J., van Petegem, P., Lamote, C., Boonen, T., \& de Bilde, J. (2012). The role of teachers' expectations in the association between children's SES and performance in Kindergarten: A moderated mediation analysis. PLOS ONE, 7, e34502. doi:10.1371/ journal.pone.0034502.

Tenenbaum, H. R., \& Ruck, M. D. (2007). Are teachers' expectations different for racial minority than for European American students? A meta-analysis. Journal of Educational Psychology, 99, 689-705. doi:10.1037/0022-0663.99.2.253.

Timmermans, A. C., Kuyper, H., \& Van der Werf, M. P. C. (2013). Schooladviezen en onderwijsloopbanen: Voorkomen, risicofactoren en gevolgen van onder- en overadvisering. [Track recommendations and educational careers; Prevalence, risk-factors and consequences of high and low track recommendations]. Groningen: GION.

Timmermans, A. C., Kuyper, H., \& Van der Werf, M. P. C. (2015). Accurate, inaccurate or biased teacher expectations: Do Dutch teachers differ in their expectations at the end of primary education? British Journal of Educational Psychology, 85, 459-478. doi:10.1111/bjep.12087.

van den Bergh, L., Denessen, E., Hornstra, L., Voeten, M., \& Holland, R. W. (2010). The implicit prejudiced attitudes of teachers: Relations to teacher expectations and the ethnic achievement gap. American Educational Research Journal, 47, 497-527. doi:10.3102/0002831209353594.

Anneke C. Timmermans is assistant professor at GION Education/Research of the University of Groningen, the Netherlands. Her main interests include educational effectiveness, methodologies for estimating school effects, multilevel modeling, educational transitions and teacher expectations.

Hester de Boer is a post-doc researcher at GION Education/Research of the University of Groningen, the Netherlands. Her research interests include expectations and aspirations of teachers and parents and their influence on student academic performance, and the effects of the attributes related to the implementation and evaluation of educational intervention studies.

Margaretha P. C. van der Werf is full professor of learning and instruction at the University of Groningen, the Netherlands. Her main interests include educational effectiveness, civics and citizenship education and the influence of psychological precursors of school success. 